\begin{tabular}{|c|c|c|c|c|c|c|c|c|c|c|c|c|c|c|c|}
\hline & \multicolumn{3}{|l|}{9} & \multicolumn{2}{|r|}{ 號 } & 六 & & + & 八 & 百 & \multicolumn{2}{|l|}{ 第 } & & \\
\hline & & & & & & 呈 & & & & & & & & & \\
\hline & 球 & 種 & $\bar{I}$ & כ & t & 咅 & 而 & & & & HAH & 非 & 疑 & 雖 & 唋 \\
\hline 混 & $\begin{array}{l}\text { 骨 } \\
\text { 穷 }\end{array}$ & $\begin{array}{l}\text { 存 } \\
\text { 在 }\end{array}$ & 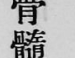 & ¿ & , & $\begin{array}{l}\text { ㅁ] } \\
\text { F }\end{array}$ & $\begin{array}{l}\text { 盀 } \\
\text { 疗 }\end{array}$ & & & & (1) & r & 挿 & 弇 & 䒨 \\
\hline 畣 & 篮 & $\mathrm{t}$ & 7 & $\begin{array}{l}\circ 8 \\
0.8 \\
0\end{array}$ & 次 & 藏 & $\exists$ & & & & & 241 & 2 & 處 & 例 \\
\hline 性 & 細 & 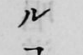 & 以 & $\frac{\mathrm{\sigma}}{\mathrm{\sigma}}$ & $\bar{j}$ & 器 & 始 & & & 0 & 사 & के & 铨 & 知 & th \\
\hline & r & $\overrightarrow{\vec{r}}$ & 源 & 5 & $\underset{k}{\mathscr{S}}$ & 着 & $\bar{F}$ & & & 模 & & $=$ & 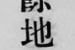 & 梠 & $\neq$ \\
\hline & 認 & 会 & 泉 & స్ & 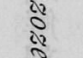 & 眼 & 覺 & & & 範芦 & d & (3) & 無 & $=$ & $凡$ \\
\hline & $\begin{array}{l}\text { 台 } \\
\text { 严 }\end{array}$ & 苓 & 篇 & $\Xi$ & 8 & $\stackrel{\ddot{J}}{\bar{J}}$ & 問 & & & 的 & \{ & tif & $\stackrel{7}{7}$ & 就 & 蒷 \\
\hline 例 & $\neq$ & - & $\ddot{z}$ & $\bar{c}$ & $\sharp$ & 白 & $=$ & & & 混 & \{ & 17 & 信 & 腺 & 柱 \\
\hline & 大 & 般 & 脾 & 7 & हี & 衂病 & $\begin{array}{l}\text { 記 } \\
\text { 裁 }\end{array}$ & & & 弇 & $\xi$ & 䦗 & ㅈ. & 苫 & 上 \\
\hline & 形, & 承 & 怔及 & 加 & 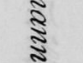 & $\begin{array}{c}\text { 病 } \\
\Rightarrow\end{array}$ & $\begin{array}{l}\text { 載 } \\
\text { the }\end{array}$ & & & 性 & \{ & 38 & 纱 & $\begin{array}{l}\text { 趈 } \\
\text { 細 }\end{array}$ & $\begin{array}{l}\text { 皮 } \\
\text { 細 }\end{array}$ \\
\hline & 細 & 認 & 榃 & $\bar{z}$ & 等 & 脾 & シ & & & 具 & \{ & 1) & $=$ & 胞 & 胞 \\
\hline & 胞 & セ & 巴 & 咅 & 妿 & $\begin{array}{l}\text { 臓 } \\
\end{array}$ & 产 & & & 吕l & $\xi$ & II & 於 & 盾 & 기 \\
\hline & 見 & 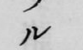 & , & 糧 & 帛 & 14 & $\begin{array}{l}\text { 胃 } \\
=\end{array}$ & & & 讷 & $\xi$ & $7 \frac{15}{2}$ & 力 & 惟: & 成 \\
\hline & $\pi$ & $\nu$ & 變 & 成 & 皿病 & $=$ & $\rightarrow$ & & & 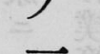 & $\xi$ & 31 & 吾 & 增 & 立 \\
\hline & $\vec{z}$ & 所 & 炛 & 즐 & 患 & $\frac{\tilde{D}}{\sigma}$ & 分 & & & 例 & $\xi$ & 87 & 人 & 息 & ${ }_{j}$ \\
\hline & $\exists$ & $y$ & 以 & 至 & 者 & 5 & 五 & & & {$[y]$} & & & ビ| & 來 & 癌 \\
\hline & 得 & & $\bar{F}$ & 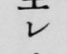 & 骨 & हू & 年 & & & & $\xi$ & +4 & 2 & Ł & 種 \\
\hline & $\hat{z}$ & 霯 & 繯 & !) & 髓 & $\stackrel{0}{\Xi}$ & $\leqq$ & & & & $\xi$ & & 品 & 㮌 & $\begin{array}{l}= \\
\pm\end{array}$ \\
\hline & . & 召 & 的 & 爾 & 中 & ㄹ. & $\overrightarrow{\mathrm{D}}$ & & 山 & & $\xi$ & 秘 & 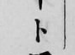 & 䉀 & $\bar{J}$ \\
\hline & X & 吾 & ' & 來 & 主 & 及 & $\stackrel{\varrho}{\nexists}$ & & $=$ & & $\xi$ & 5 & 昏 & 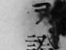 & 的 \\
\hline & 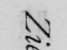 & 八 & , & 幾 & 要 & 淋 & $\exists$ & & 於 & & 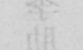 & 3 & 佊 & 暗 & \\
\hline & $\alpha_{2}^{2}$ & 血 & 1 & , & F & 㝭 & 以 & & $v$ & & 谙 & $=$ & 3 & $\pi$ & 1 \\
\hline & 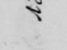 & 液 & 見 & 學 & 戀 & 恃 & 愺 & 久 & 病 & & & $z^{2}$ & 必 & 12 & ゼ \\
\hline & 骨 & 錇 & 秙 & 省 & 华 & $\bar{\Xi}$ & 垁 & & 珵 & & 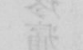 & 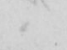 & 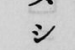 & r & வீ \\
\hline & 髓 & 檢 & ) & 依 & 有 & $\underline{z}$ & 1 & & 教 & & $F$ & 当 & $E$ & & \\
\hline & 统 & 攴 & 卢 & $\bar{z}$ & 7 & 莺. & 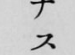 & 保 & 室 & & 54 & the & $\begin{array}{l}\text { 信 } \\
\text { 據 }\end{array}$ & 得 & $\ddot{3}$ \\
\hline & 篟 & 型 & 㿢 & 照 & $\begin{array}{l}\text { 洼 } \\
\text { 音 }\end{array}$ & مٍ & $\because$ & & $\vec{y}$ & & 留 & sec & 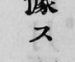 & 基 & 第 \\
\hline & 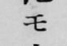 & 細 & 血 & Ł & 息 & 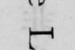 & 當 & 信 & & & $t+$ & « & N & 轉 & \\
\hline & 亦 & 胞 & 病 & $\overline{5}$ & \pm & $\cong$ & 時 & & & & & & 足 & 栘性 & 管求 \\
\hline & 續 & 髣 & 淋 & 殊 & D. & 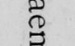 & $\therefore$ & 7 & & & & & $\overline{5}$ & 腫 & \\
\hline & 發 & 鬁 & 巴 & $=$ & 㐓 & है. & 主 & $<$ & & & & 完 & サ & 瘍 & 充 \\
\hline & 的 & 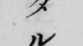 & 览 & z & 骨 & 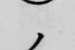 & s & 沭 & & tat & & 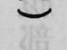 & 7 & 非 & ב \\
\hline & シ & 小 & 蓇 & ミ & 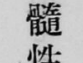 & $=$ & $\bar{J}$ & & & & & & 感 & サ & \\
\hline & $\bar{z}$ & 形 & 膸 & ב & 性 & 種 & 㱍 & & & & & 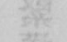 & セ & v & \\
\hline & 以 & 白 & 性 & $\therefore$ & 血 & 㗐 & 货 & & & & $x$ & $F$ & 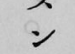 & 点 & x \\
\hline & & & & & & & & & & & & & & & \\
\hline
\end{tabular}


瀶明訴振 明 シ 雨 患

床治シ’治コ漞 著

的兰飞症全莡

猃干心狀干無觉

斷季, 七名弟

年壳篇年圣等

十隻二五骨入

白一總量皆

血視㱍頃 關 健

病圭吕章節 在

豆害蕳左疾: 六

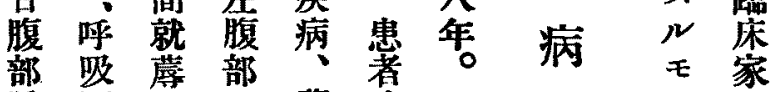

属 困 $七$ 黃生

物難り腫疸东

等、物、健

訴 7 其, 打康

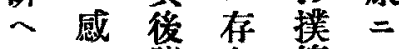

$\exists$ ス 都 在 等

以 2 症 $\Rightarrow$ \%

テ $コ$ 輕 自 既 嘗

入卜快覺往亏

院+シ 方症慢

、力農 續 7 性

診り事亦有卢

療 $\neq$ 左七利

$\exists$ 、營季

乞月公肋 0 傅

$>$ 䋑 = 部

八至二

已疼

二、痛

本當 7

年時起

四殊

月 = 發

䝿多㢣

y $=$ 身

潮 至 體

州 テ

せ 腹 湥

ス 部 意

云緊 食

フ雨思

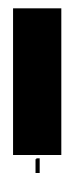

第 例 解

7 剖

記 家

載 站

ᄌ 踽

,

歷 單 實

$=$ 䮦

桸 $=$

有上

$+\quad \frac{1}{2}$

N

단

例決

卜

シ テ

テ 僅

少

䟻二

昧 非

$\Rightarrow$ 주

趼 、

玩 而

ス 方

ㄷ

千 浘

, 合

二 性

非白

サ 血.

2 病

$+\quad 7$

1) 以

最

千

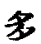

スク 二 涘

不傳 病

明染,

二說 原

屬 7 因

ᄌ 呾 7

- 道 然

问 $九$ 么

後 ル

尚 二 二

手呈

學 レ ラ

者り ス

础章

究, 七

$\Rightarrow$ 如

要 夕

ス 諸

ル 謨

モ 絕 今

,,

多 如

力 シ

N

可 綮 血.

殊 拾 液

桨 ス,

病處偡

理 7 場

解 知

剖 ラ シ

的 $ᄌ$ F

交绫

敬 中 明

察 其

二登 試

竢 生 三

的

モ 原 今

, 因

少二 其

力至 他

ラ テ

サ $心-$

$n$ 今 派

$\Rightarrow$ 日

信 全 䢒 


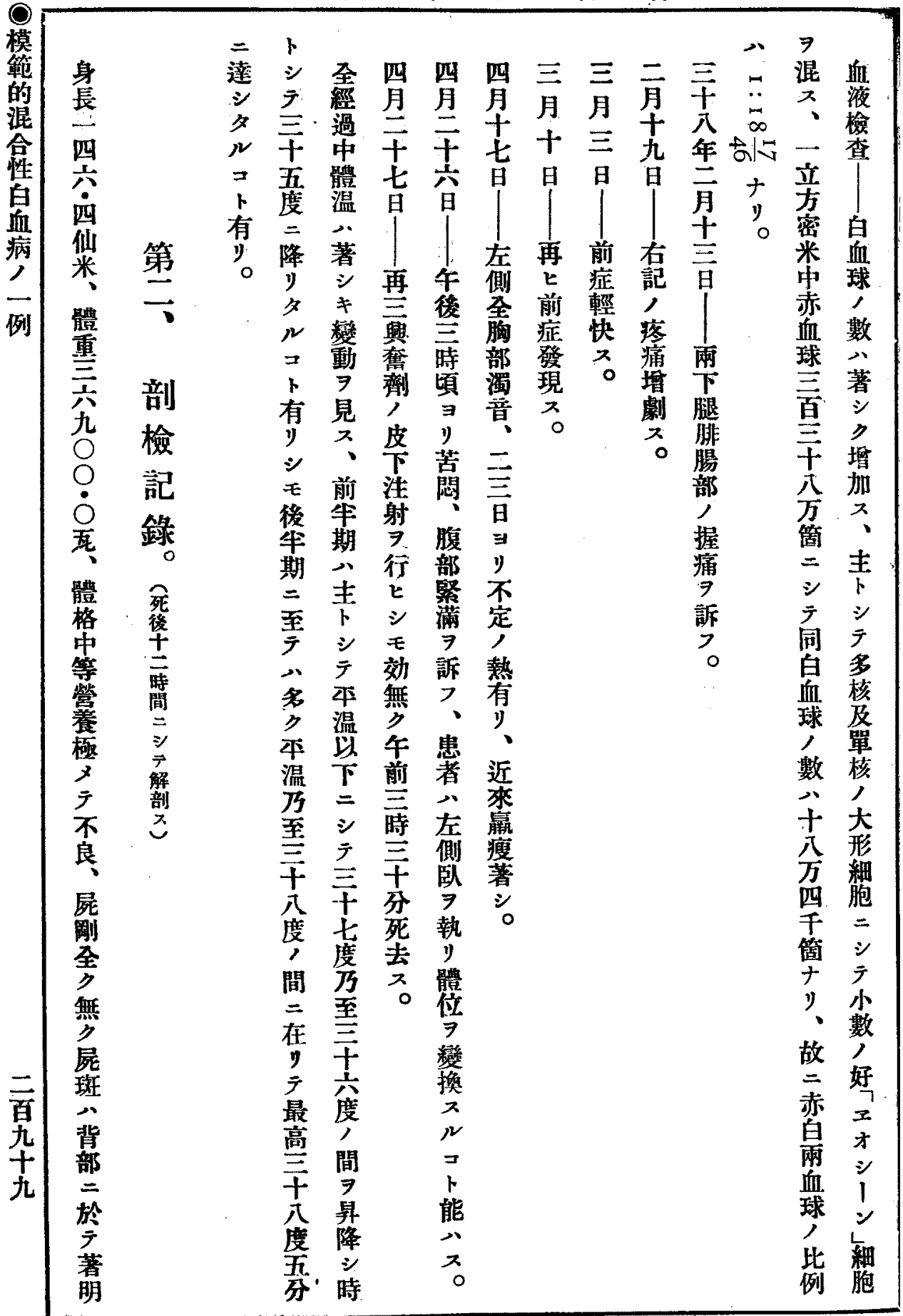


號亲十八百第

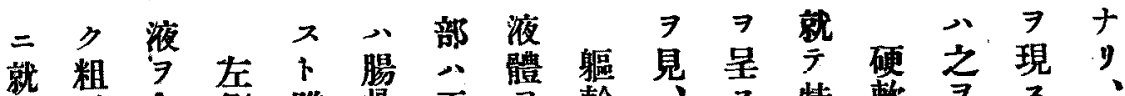

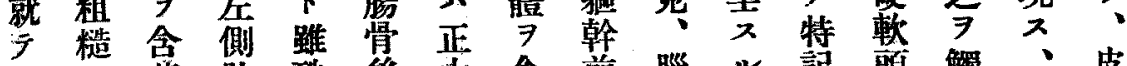

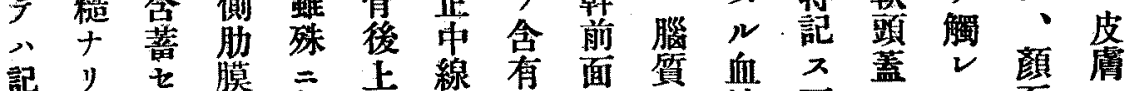

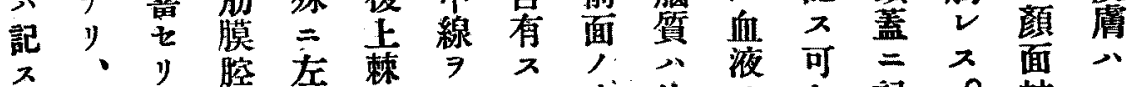

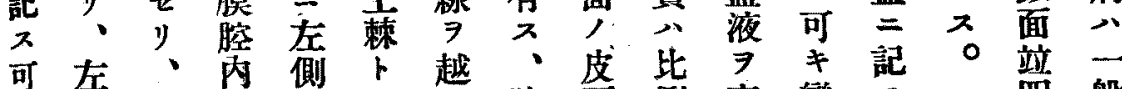

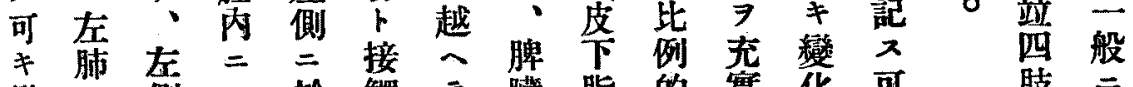
變 八側 八於 觸于臟脂的實化可 肢二

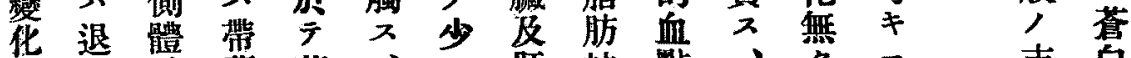
無 縮 壁 黃著・

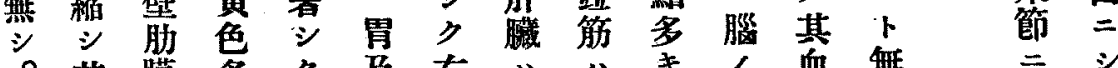

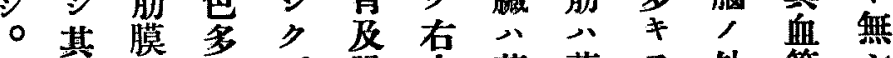
表面少下腸方著菲 $尹$ 外管

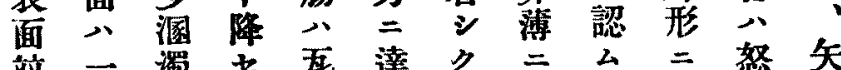

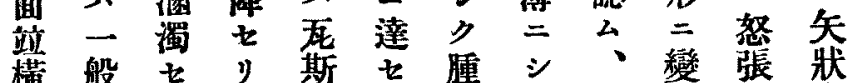

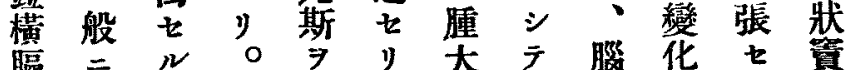

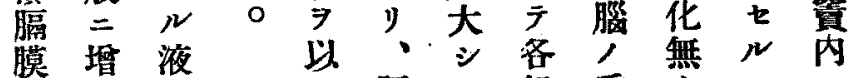
人厚體 テ肝テ組重りモ= 上 $\quad 3$

面 帽 含

二針有

八頭 2

諸大 ル

所 万

二至卜

疮 至

狀 粒. 三

方 大 $\overline{\mathrm{O}}$

至, 0

怔莫灰官

色 死

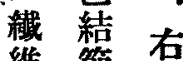

維 節 右

膨 八腹織量 側ノ八

满 其膑 間一室多牛

柆)二一丙

爾坥大八四脈、凝

餘二部漿七絡 腦 固

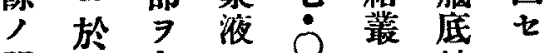

間，三占，只望点

隙季領眝虏著頭血

$\exists$ 肋七溜 少蓋液

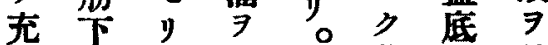

塞二、見菺二稍

七現 就

》) 中

、 脾 腹

橫 $ハ$ 膑

性 $\Rightarrow$ 证

膈 $コ$ 其 内

質密 於

算 生

附祀毛

着力

ス 篇

表?

右 面.

側 $八$ 死

胡甚.

膜多同 腔 $三$ 㧼

白翼 $ヤ$

大常大

y、無 量

- $3=$

菱 橫 含

形 䆩 有

下

窩 丙

高㭆聒稍 = 二 其

サ至骨

八元縫 大

確 仙 合 量

定 米 =

ス二接帶

ル シ 贾

コテ 前 色

卜右緣澄

能下, 明

八, 绝

數 米已

條 凝 三

, 固 淡

怒 性

張, 、

七带 軟

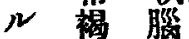

血 赤 膜

$=\dot{\Sigma}$

$\therefore$ テ

輕 兴

度色

浮 率

電 人

有》

、腹

顎 部

下

及 膨

鼠雨

蹬

广

淋 紫

巴色

腺 $\Rightarrow$

> 呈

多

少

曆 所

大 务

七

N.

モ

人 腹

$>$ 部

$v=$

卜 八

モ著

腋 明

窝,

$=$ 婎

在 娠

管 色 = テ 線 
0

I3

號

六

$+$

式百

第

模

大ス分認

的

混

弇

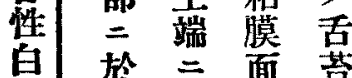

血 笶近面

病

例

箈處诚被

\section{其， 入抵}

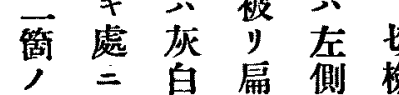

深於色桃

$\neq \overline{\bar{z}}$ 電腺

截 - 粒品

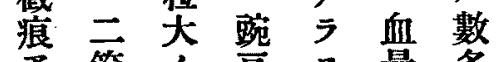

䇫, 豆量多

》處結

、横 䬣 =

少躃 $\Rightarrow$ 腫

亦膜密大

外, 生 七

面下齐,

, 面 粗

上程食

端新士檤

生y柆

近血。瓷

管

處 $\exists$

三 證

於明

天

殆

r索

全獎

横

徑 組

三織

亘 $\Rightarrow$

量

三 線

宣牀連

截 結

痕七

原”。

更。

基基

上正
頭

$=$

著

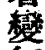

無

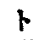

踓

氮

管

左

右

氮

昱

$=$

分

枝

七

公

r $\Rightarrow$ 次 見、 入 是 卜 等

踓,

讄 結

所 節

二

粟表

粒 面

大

灰 笑

白

色

, N

結 コ

篩

少

散手

在

故

y

随㝟

門 其

部 存

於隽
瓣帶 體

奶如、强左膜七地 淋得肺面 $\neq$ 而夕肺韭倘浸 大 东潤 內 腺 $几$ 外大結 $; \bar{゙}$ 容動線 $=$ 人所面部節灰顆積脈牀佈壬 變多二八相白粒小起乃稍 化产就乾融色牀二根至多中

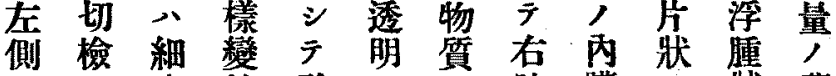
卜入性殆， 肺膜，脎黄

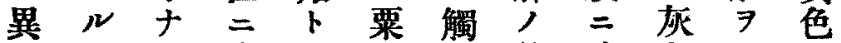
陷肺粒心約病白呈澄 組大言變色七明

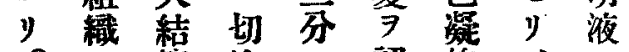
马䈱 检, 認塊、妇 認 $尹$ 入一ヌ 子散 $⿻$ 二挗璄有

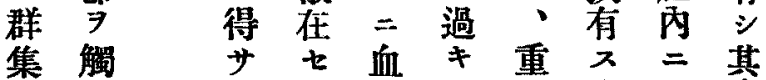

$\mu$ 液

所、前、至畐䌅面

有此空䏚三膜多二

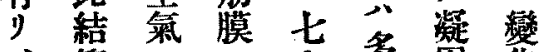

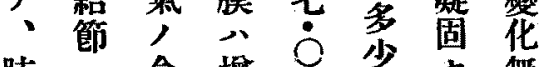

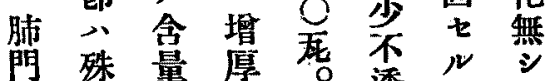

部三至涹。

下厚

淋葉少 多

巴多織

腺下肺維

公部察膜

䲧三覔

率多公附

大多肝着

且, 世

缠形切》

大面、

七刀按

江見糜

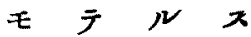

, 下

7 萧如

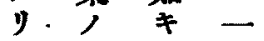

而最觀般

\% $7=$

厂端呈抗

充 外
明液 心

倠 7 臟

呈實 摬

政

箶擬 比

淡 血 例

跡一的

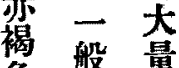

色 般量

三脂

多肪

柔偝

秉含

色色液

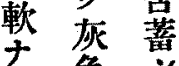




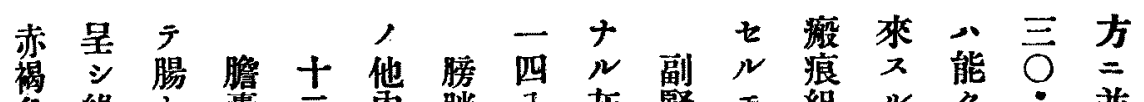

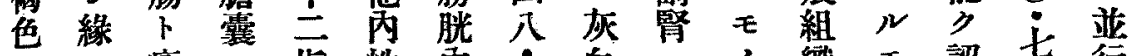

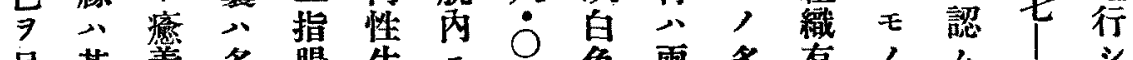
呈甚着多腸生二互色雨多有人公

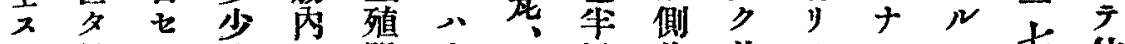

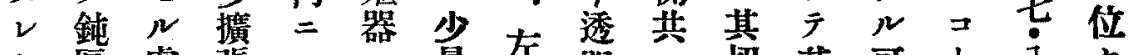

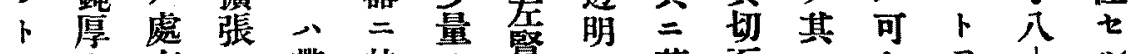

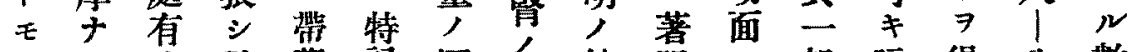
小りy稀黄記溷處結明心部暗得八數

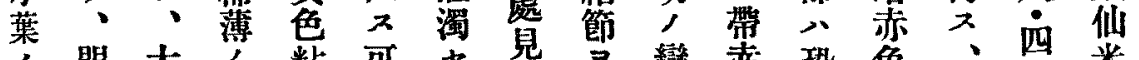

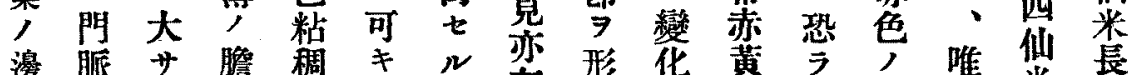

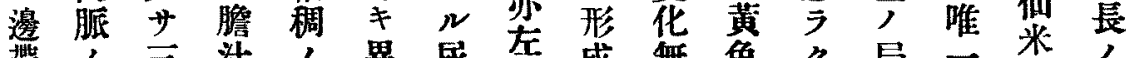

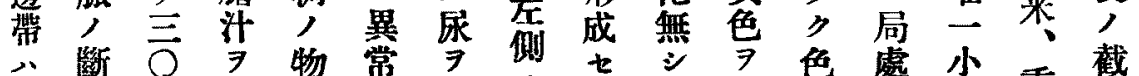

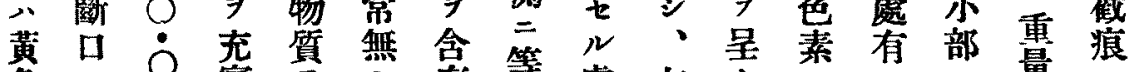

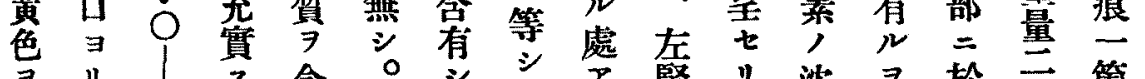

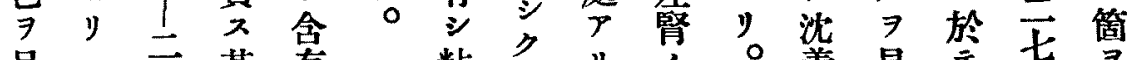

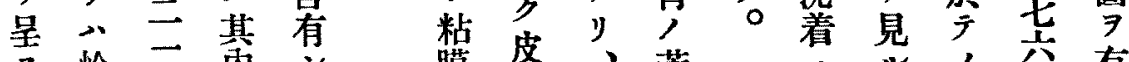

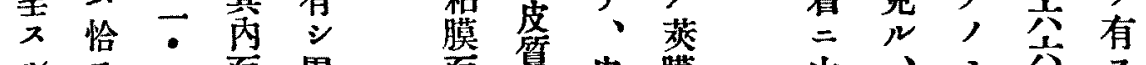
$\nu$ モ $\rightarrow$ 面 胃 力 $1=$ 內 故窐 七 著 $=$ 闩

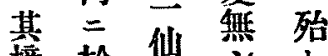

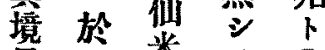
界々 米、内 八重肝容 制卜重藏物 明同 量 $>7$

漛 吾著見

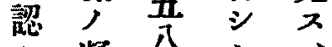
么 凝 $\mathrm{O}$ $\nu$ 血 ! 增 雨 $\exists \exists \dot{0}$ 大 粘 卜大瓦 $三$ 膜 $\exists$ 量、左面 得三表葉 脫面，記 而出公 海面可 天り澤、キ 胙 $=$ 索.

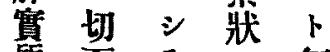

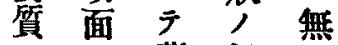
“黄 組 切一褐擮。

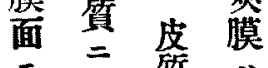
於筫八

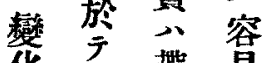

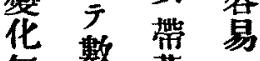
無罊董 产苗色剥 灰丕離 亮稚透 , 色= =

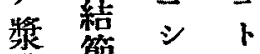

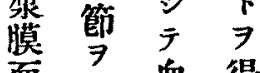
面責血得 $=$ 見量 於少、䨓

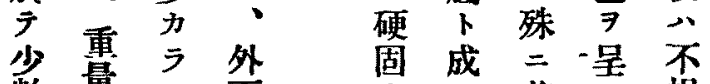
數量

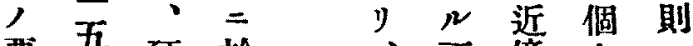
整吾硬於、不傍多三

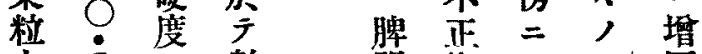
大 $\mathrm{O}$ 數門櫂公江厚

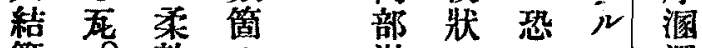

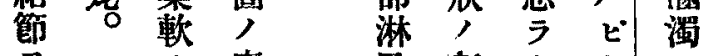

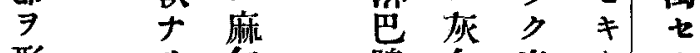
形・货 成等 面般色录

重㽜

腺白出的 八色血氏 䐺 $千$ 二小 大 $ル$ 由唓 


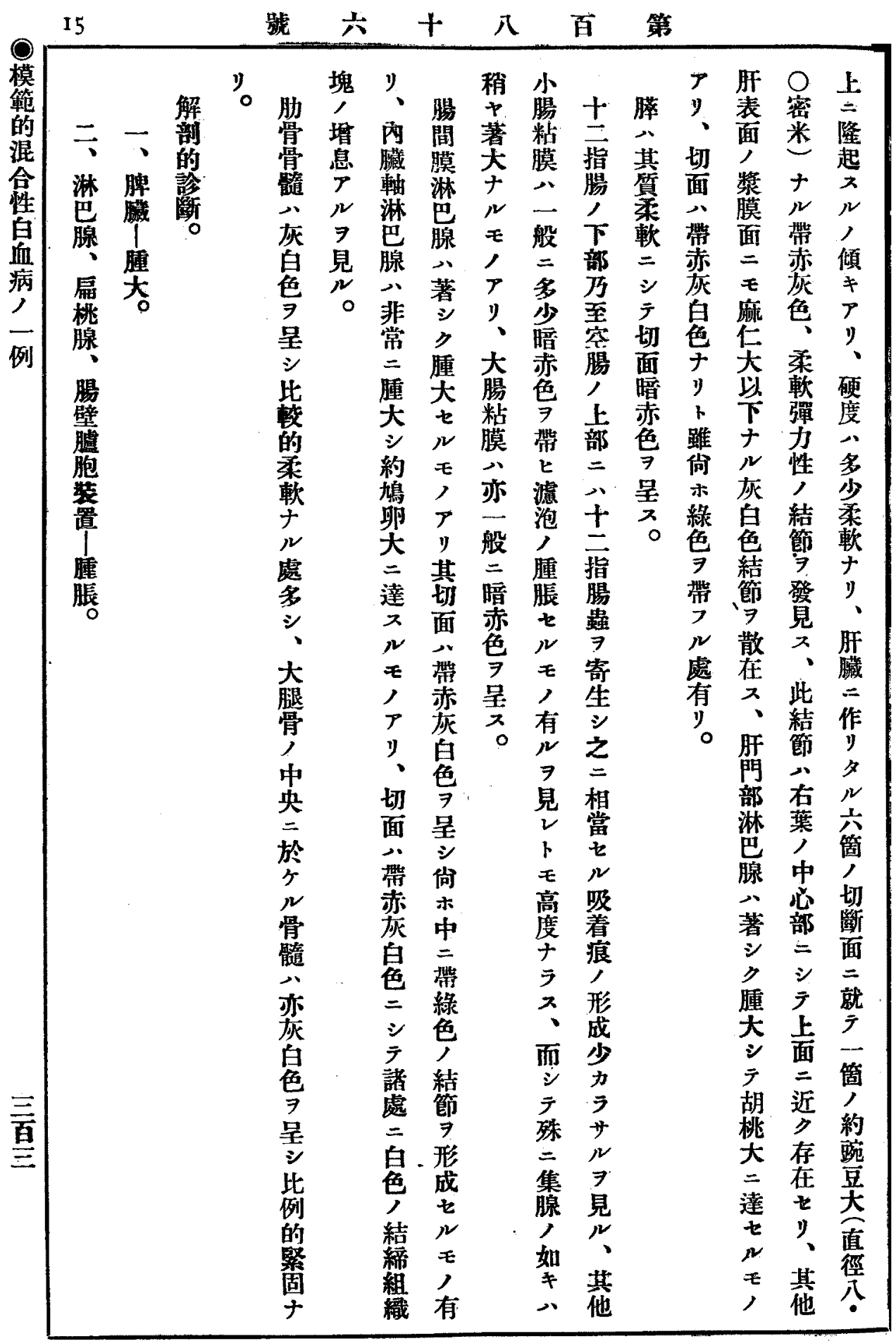


數 所 $フ$ 球 $七+$ $\exists$ 謂り狀 ル紅氏 占淋殊核モ八血染击 公巴二⿻，猶球色者 ○細細有、条三涹了 脆顆 入 漂 紅 就依存 $=$ 粒 $N$ 子血 $テ y$ 中 類狀モ 狀球

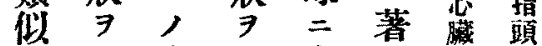
七呈有呈劣 j ᄌ y

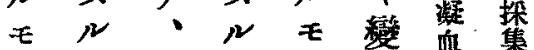

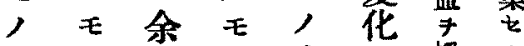
他, 心, 有 八有五 或 y 認甬血 大り、筒 大 大 形、人三十 二要核三心、成剖

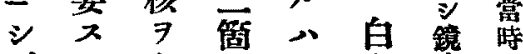
デ有, 其血检出 骨二ス小數球 、幦 髓白八核倍八其及 細 血 細力二紅虞㬝 胞球 胞細薘血基臟 $==\exists$ 徑又球左切 髺 就 認 $7 ハ=$ 如斷

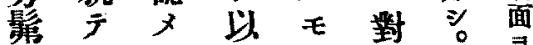
夕八得 $\bar{\gamma}, \quad \equiv$ 雨夕僅 $尹$ 著流 モ筒り、カ 認 , $>=厶$, 之種核連核其 》 $\Rightarrow$ 染七, 7 、區色儿形增 概 妿 方 $モ$ 狀 加 沙 亏得又多》。 後人種入繁、 者シ \&全二大 、、 $=3$ シ

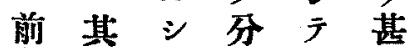
者 一テ離 秙夕 ヨ八濃七狀不 リ小 $\neq ⿻ 上 丨$ モ形 $>=$ 常三》三盯 = 淡箇彎 多手屈小

出

セ

血

液

龺

年

テ"

\%

$\neq$

$\not n$

F

x

標

本

$\neq$

製

シ

口

>.

I.

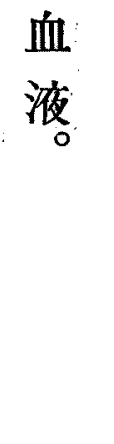

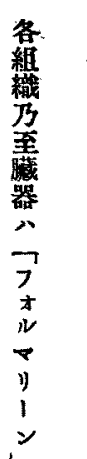

是面

微

競

的

虎

㔔見

第

硬

䋨

㙕
五四三

十左 肝

搉肕

法

依

テ

7

곤

,

4

1

但

童

行

䓡

微

鏡

的

標

本

作

No 


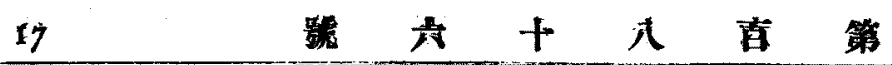

- $=$ 核

的 $y ; 3$

䇚

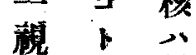

殊大而大 淋

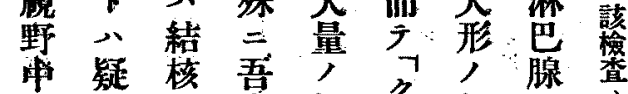

混

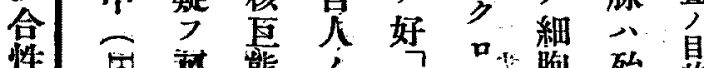

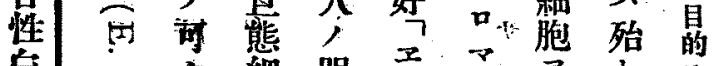

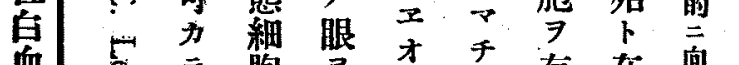

血 恖

病㣽

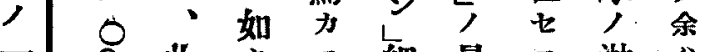

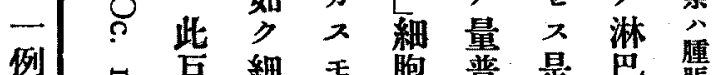

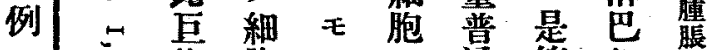

○態胞ノノ通等細

导細 $>$ 混少細胞丙

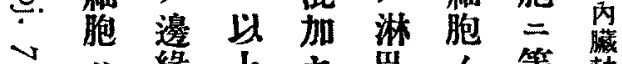

৩ 心䋑上七等 軸

く腺二广几 細核

$\stackrel{9}{\circ}=$ 其 細 7 胞

依長胞見寻多細瞙

wy 軸間父り多胞箖

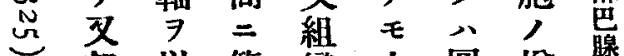

部 以 箱 織 少 圓 剒 䛲

五 分 テ 在 間 $\neq$ 形数 間

十二並七二力㭆二 部

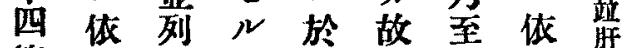

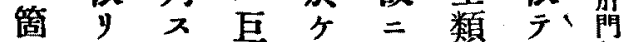

ノテル態 ル能圓堽部

多集力細細力形大沙

₹散 如胞 血兩二

$\exists-\neq=$ 管種 $シ$ 甹腺

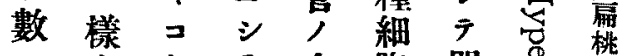

人十ト 血胞單祃腺

得 ラ 無 二球, 二总及

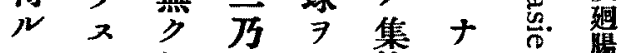

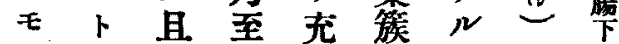

雖胞三害 $\ni$ モ

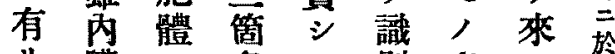

リ践二多テ别多 シ 方

、軸富 $\neq$ 撗 シ

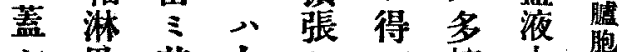

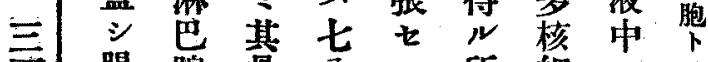

腸腺骨入所細 $==$

五

臄於吉, ,

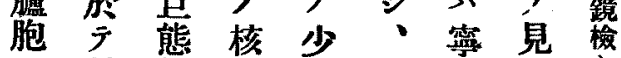

二最細 $尹$ 力其品多怘

於毛胞有亏他稀心 。

III. 張 >

II.

七左

泝 ル、側

U, モ而 第

裝比 テ 䎡

置例固骨

的有及

多, 右

冎 側

$\Rightarrow$ 䯕 大

認 巨腿

么 態 骨

$\nu$ 細 二

二胞 就

$卜 \quad$ ○

$\Rightarrow$ 如 檢

得 $\neq$ ス

可 $モ N$

涪 譇

落起

$=\quad$ シ

栖霞

邓 淋

テ巴

少性

量 倠

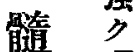

數 絴

二 胞

發,

見增

シ 數

得 7

求

$=$ シ

過 脂

干 肪

ス絴

、胞

$x$

才

シ

ע

7

b

テ

染

任

七

v

好

조

才

シ

ข

血管 如

都

胞

テ多ナス $九$ 比有力

$\therefore \quad$ F

血心

液 殆

8

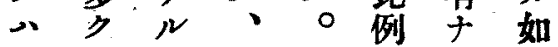

$\exists$.

完見

䨘 ル

$\frac{20}{=}$

要

总

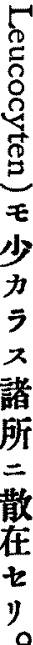

テ 卜

擴 能 
VI. 埭 䄉 破

脈 $心$ 潰 朋 睯公强有”, 藏著名稂

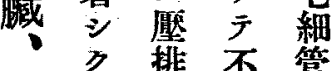
擴七規 臟 張 $三$ 則 强 蔵 $九$ 度 陁 $\nu$, 血 $=$ 肺 $千$ 千球撗 及, ', 張 少有氾 脺 分濫血 今之球

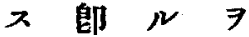
、 7 以 間肉見至 算眼光克 秥的 满 綵灰 其 組泉度亏 織色强几 $=$, 稆 八結モ天 暮節, 肝 延妇、稩 性成畧脃 $=$ 七自 白 $几$ 圆它 血所形 球謂, 曆 , 淋簛迫 浸暨意

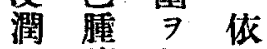
七㴼劃 $\nu=v^{*}$ 處一开篗 多致血 咅球y

モ 集 又 ，霣墸 ナ、笋處 y) 來 $=$ - 䀘 又: 周 組 中i周織 心組,
$\mathrm{V}$, 白, , 區 血 反色别包 肝病應素学膜 $=\exists$ 顆能 臟於检粮 石专少 ル遺ル著 紅 $\mathrm{k}$ 音 血丰恐至》 球八分㙁 , 脾”、擪 崩, 出又七 潧組血表》 力峨䇫在。 力中，部實 埇 二形三䫓 進於成於心 济有亏 邓 必少核同 益汎 $シ=$ 類 合 こ之型 紅 性 1 背細 白 $=$ ₹胞 血通想髹， 球常像粗 , , 數度 三結 马公䋨爽 接越、組 近至加霏、 七 之性脾 格一分旅材 公乎痕 半1 在尚 二血夕夕多 非色，广諸 茾素氏表虎 江法面三 無存三三散 年在㨜陷在 力七沒 $\exists \mu \neg x$ 大 $尹$ 、 見此王 疑觉齐部墟 言余兴绝 台弈! 靄至
IV. 明 此 新腸 脾 得䦔 細 臟 关范 前 7 門 發 部 見 , ᄌ 淋 巴 腺卜

二 能

八

偶

發

,

變

化

r

シ

テ

中

心

部

乾

酪

樣

變

性

$=$

傾

r

次

結

核

性

病

覆

在

州

$\bar{\gamma}$

結

核

菌

画 


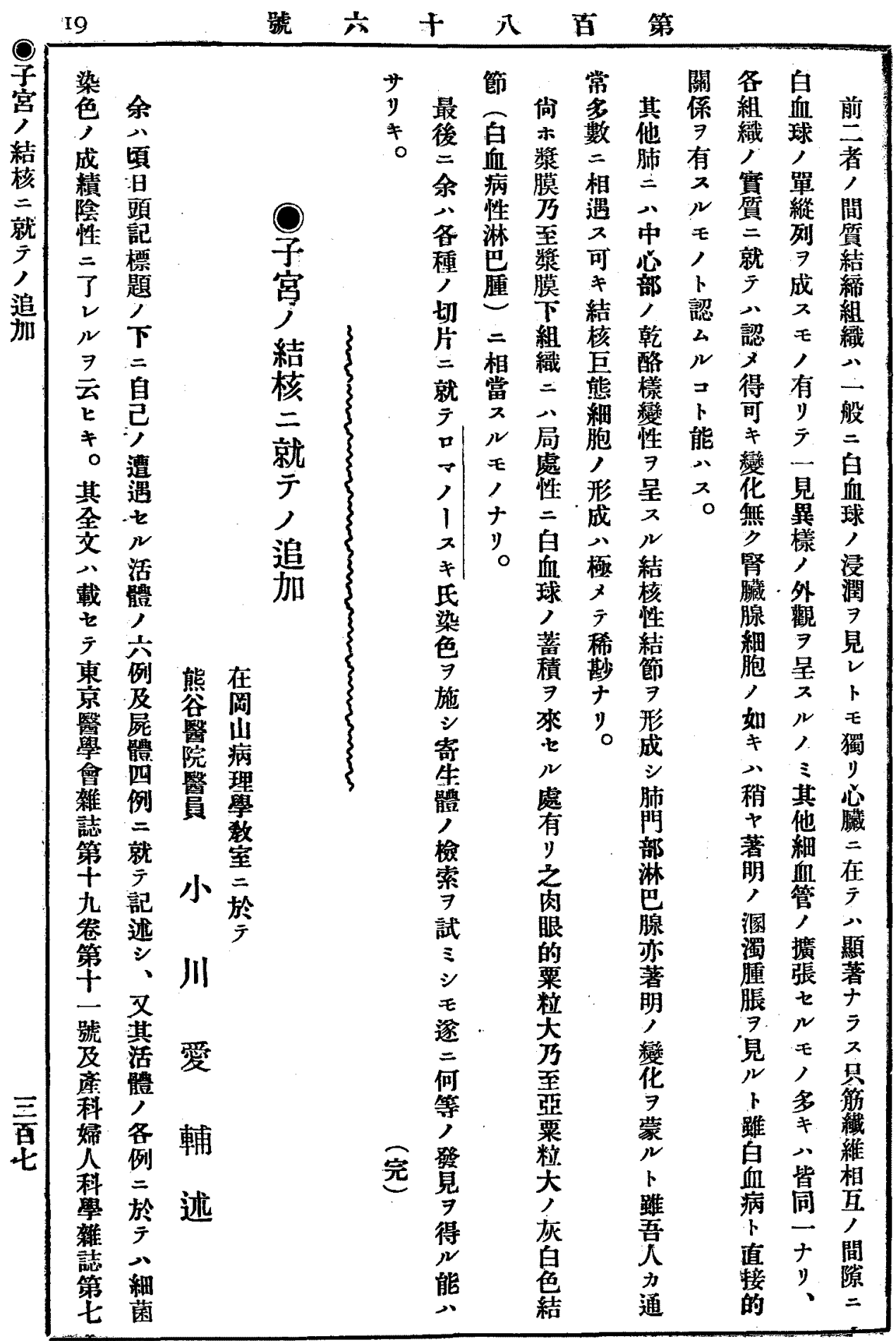

